\title{
ANALISIS PENGARUH PENGGUNAN UANG ELEKTRONIK TERHADAP PERILAKU KONSUMTIF MAHASISWA PENDIDIKAN EKONOMI UNIVERSITAS INDRAPRASTA PGRI
}

\author{
Oleh: \\ Dwi Rorin Mauludin Insana ${ }^{1}$ \\ Ria Susanti Johan ${ }^{2}$ \\ ${ }^{1}$ Program Studi Pendidikan Bahasa Inggris, Fakultas Bahasa dan Seni \\ Universitas Indraprasta PGRI Jakarta \\ ${ }^{2}$ Program Studi Pendidikan Ekonomi, Fakultas Ilmu Pendidikan dan Pengetahuan \\ Sosial, Universitas Indraprasta PGRI Jakarta \\ Email: \\ dwirorin@gmail.com
}

\begin{abstract}
ABSTRAK
Tujuan dari penelitian adalah untuk menganalisa apakah terdapat pengaruh penggunaan uang elektronik terhadap perilaku konsumtif mahasiswa Universitas Indraprasta PGRI. Metode penelitian ini menggunakan metode survey dengan angket. Jumlah populasi yang diteliti adalah 430 orang dengan sampel 81 orang. Berdasarkan hasil penelitian diperoleh nilai tingkat sensitivitas perilaku konsumtif terhadap penggunaan uang elektronik itu sendiri adalah $32 \%$ yang ditunjukkan dengan koefisien regresi $\mathrm{Y}=42,26+0,32 \mathrm{X}$. Sedangkan koefisien korelasi sebesar 0,325 dan koefisien determinasi (KD) sebesar 10,56\%. Kemudian dalam uji hipotesis diperoleh nilai $t_{\text {hitung }}$ sebesar 3,085 dan $t_{\text {tabel }}$ sebesar 1,664 atau $t_{\text {hitung }}>$ $t_{\text {tabel. }}$ Kesimpulan penelitian ini bahwa penggunaan uang elektronik berpengaruh positif dan signifikan terhadap perilaku konsumtif mahasiswa Pendidikan Ekonomi Universitas Indraprasta PGRI tetapi memiliki korelasi yang rendah dengan kontribusi variabel penggunaan uang elektronik sebesar $10,56 \%$ terhadap variabel perilaku konsumtif mahasiswa dan sisanya sebesar $89,44 \%$ dipengaruhi oleh variabel lainnya.
\end{abstract}

Kata Kunci: mahasiswa, pembayaran non-tunai, perilaku konsumtif, uang elektronik 


\begin{abstract}
The purpose of this study was to analyze whether there is an effect of the use of electronic money on the consumptive behavior of students at the University of Indraprasta PGRI. This research method using a survey method with a questionnaire. The population studied was 430 people with a sample of 81 people. Based on the research results, the sensitivity level value of consumptive behavior towards the use of electronic money itself is $32 \%$ which is indicated by the regression coefficient $Y=42.26+0.32 X$. While the correlation coefficient is 0.325 and the coefficient of determination $(K D)$ is $10.56 \%$. Then in the hypothesis test, the $t_{\text {count }}$ value is 3.085 and the $t_{\text {table }}$ is 1.664 or $t_{\text {count }}>t_{\text {table. }}$. The conclusion of this study is that the use of electronic money has a positive and significant effect on the consumptive behavior of students of the PGRI Indraprasta University Economic Education but has a low correlation with the contribution of the variable use of electronic money by $10.56 \%$ to the student consumptive behavior variable and the remaining $89.44 \%$ is influenced by the variable other.
\end{abstract}

Keywords: students, non-cash payments, consumptive behavior, electronic money

\title{
A. PENDAHULUAN
}

Teknologi informasi yang semakin berkembang saat ini telah menggeser fungsi uang tunai yang dari dulu dipakai oleh masyarakat sebagai alat pembayaran pada umumnya menjadi uang non-tunai yang dirasa lebih efektif dan efisien. Melalui teknologi saat ini setiap orang dapat melakukan transaksi melalui sebuah aplikasi yang ada di smartphone tanpa harus repot membawa dompet dan uang tunai, karena pengguna bisa melakukan pembayaran digital dengan mudah, aman dan dalam waktu singkat.

Perkembangan teknologi dalam hal pembayaran menjadi salah satu gaya hidup masyarakat pada zaman modern. Sistem pembayaran non-tunai menjadi trend terutama di kalangan anak-anak muda. Perubahan sistem pembayaran sangat pesat mengikuti perkembangan teknologi, hal ini menjadi peluang bagi perbankan untuk bersaing dalam hal sistem pembayaran non-tunai. Kecepatan, kemudahan, keamanan dan kenyamanan dalam bertransaksi menjadi alasan masyarakat Indonesia beralih terhadap sistem pembayaran non-tunai. Sistem pembayaran yang efisien dapat diukur dari kemampuan dalam menciptakan biaya yang minimal untuk mendapatkan manfaat dari suatu kegiatan transaksi jual beli. Orang-orang sudah mulai mengurangi kebiasaan mereka untuk membawa uang dalam jumlah yang tidak sedikit di dalam dompetnya, karena hal tersebut tidak aman serta tidak praktis.

Di Indonesia sistem pembayaran non-tunai (e-money) mulai dikenal sejak tahun 2007, sedangkan di Singapura sudah mengenal e-money sejak tahun 2000. Menurut Bank Indonesia pada tahun 2009 instrumen uang elektronik yang beredar di Indonesia yaitu pada angka 3,016,272, sedangkan pada tahun 2010 naik menjadi 7,914,018 dan terus naik secara signifikan di bulan Februari 2018 menjadi 200,87 juta yang beredar (Bank Indonesia, 2018). Dari data tersebut menunjukkan bahwa penggunaan e-money akan terus meningkat dan dalam 
beberapa tahun kedepan e-money dengan banyak kemudahan dan manfaat yang dimilikinya akan menjadi prioritas masyarakat didalam melakukan pembayaran. Namun harus diingat bahwa penggunaan uang elektronik bukan untuk mengganti penggunaan uang tunai secara keseluruhan, hal ini karena masih ada beberapa toko atau pedagang yang belum menerima pembayaran dengan uang elektronik.

Munculnya sistem transaksi pembayaran dengan uang elektronik membuat masyarakat terutama kalangan muda terlebih lagi mahasiswa lebih mudah dalam memenuhi kebutuhan hidupnya di antaranya untuk pembelian buku dan keperluan kuliah lainnya (Bank Indonesia, 2011; Abidin, 2015; Khairi \& Gunawan, 2019). Hal ini disebabkan karena dengan menggunakan uang elektronik transaksi belanja menjadi lebih efisien, cepat, aman, dan nyaman. Adanya peningkatan penggunaan uang elektronik oleh mahasiswa dapat memengaruhi perilaku mahasiswa menjadi lebih konsumtif (Rofiqoh et al., 2020; Mujahidin, 2020; Daliyah \& Patrikha, 2020).

Perilaku konsumtif mahasiswa memiliki aspek positif dan negatif (Tresnaatmaja, 2019) dan (Aprilia \& Hartono, 2014). Aspek positif dari perilaku konsumtif yaitu timbul rasa puas, rasa puas ini timbul karena konsumen bisa memilih kombinasi berbagai macam barang dan jasa yang terbaik dari anggaran yang tersedia, selain itu perilaku konsumtif juga dapat menambah pengalaman, hal ini terjadi apabila konsumen mengonsumsi barang dan jasa baru, yang belum pernah dipakai atau digunakan sebelumnya. Selain itu juga banyak juga dari kalangan mahasiswa yang menggunakan kemudahan penggunaan uang elektronik untuk membeli barang-barang yang kemudian dijual kembali untuk mendapatkan keuntungan dan sebagai usaha sampingan mahasiswa. Selain itu, perilaku konsumtif juga memiliki aspek negatif. Salah satunya adalah memupuk sifat dan gaya hidup konsumerisme, yang menganggap barang-barang sebagai ukuran kesenangan, kebahagiaan, dan harga diri (prestige) (raharjo jati, 2015; Saputra \& Listyani, 2017; Oktafia Mustika Rani, 2020). Dengan perilaku konsumtif tersebut akan mendorong mahasiswa tidak hanya membeli barang-barang yang menjadi kebutuhan kuliahnya saja tetapi bisa juga untuk membeli barang dan jasa yang sebenarnya belum menjadi kebutuhannya. Berdasarkan dari uraian di atas, maka penulis tertarik meneliti tentang pengaruh penggunaan uang elektronik terhadap perilaku konsumtif terutama pada mahasiswa Pendidikan Ekonomi Universitas Indraprasta PGRI Jakarta.

\section{B. KAJIAN PUSTAKA}

\section{Uang Elektronik}

Bank Indonesia menjelaskan tentang pengertian uang elektronik yang merupakan instrumen atau alat yang digunakan untuk pembayaran dengan beberapa unsur yang harus dipenuhi antara lain dikeluarkan dengan dasar nilai uang yang harus disetor ke penerbit yang dilakukan oleh pemegang, kemudian nilai uang tersebut akan disimpan di dalam media berupa server atau suatu chip secara elektronik, selanjutnya bisa digunakan untuk pembayaran kepada toko atau merchant yang bekerjasama dengan penerbit, sedangkan nilai uang elektronik yang telah disetor oleh pemegang yang kemudian dikelola penerbit tidak menjadi 
simpanan seperti yang terdapat dalam undang-undang tentang perbankan (Bank Indonesia, 2018) dan (Bank Indonesia, 2011). Sedangkan Usman (2017) menjelaskan bahwa uang elektronik adalah uang yang tidak berwujud secara fisik atau cashless money, dan nilai uangnya diperoleh dari nilai uang yang telah disetor ke pihak penerbit, yang selanjutnya akan disimpan dalam kartu chip atau server (hard drive) dan bisa digunakan untuk pembayaran secara non-tunai ke merchant atau pedagang yang bekerjasama dengan penerbit uang elektronik tersebut. Adapun Abidin (2015) menyampaikan bahwa uang elektronik adalah salah satu inovasi dalam sistem pembayaran secara mikro (retail) atau jumlah sedikit. Uang elektronik digunakan dengan cara kartu ditempelkan pada alat sensor yang ada di toko atau merchant yang diperoleh dari penerbit, apabila transaksi berhasil maka saldo yang ada pada kartu akan berkurang seseuai dengan jumlah transaksi.

Berdasarkan pendapat di atas maka disimpulkan bahwa uang elektronik merupakan alat atau instrumen yang bisa digunakan untuk transaksi atau pembayaran di toko atau merchant yang sudah bekerjasama dengan penerbit dengan menggunakan media kartu chip berdasarkan jumlah nilai uang yang telah disetor ke pihak penerbit. Uang elektronik ini menjadikan transaksi berubah dari uang tunai menjadi non-tunai.

Beberapa manfaat dari penggunaan uang elektronik menurut Abidin (2015) dan Bank Indonesia (2018) antara lain memudahkan dan mempercepat transaksi tanpa harus membawa uang tunai, kemudian memudahkan para pedagang atau merchant karena tidak perlu menyiapkan uang kembalian, dan cukup aplikatif untuk digunakan dalam pembayaran yang bersifat massal dan sering dilakukan seperti pembayaran tol, pembayaran transportasi umum, parkir, makanan, dan lain-lain.

Selanjutnya Bank Indonesia (BI) membagi jenis uang elektronik menjadi uang elektronik registered dan uang elektronik unregistered. Uang elektronik registered yaitu uang elektronik yang diberikan kepada nasanah dengan data identitas yang jelas dan teregistrasi di penerbit uang elektronik, sehingga penerbit harus memegang prinsip pengenalan terhadap nasabah untuk mengeluarkan uang elektronik registered ini, kemudian dana yang tersimpan dalam uang elektronik untuk jenis registered adalah paling banyak Rp5.000.000,00 (lima juta rupiah). Berikutnya adalah uang elektronik unregistered yaitu uang elektronik yang diberikan kepada pengguna tanpa harus memberikan data identitas untuk diregistrasi di penerbit uang elektronik. Adapun dana yang tersimpan untuk jenis unregistered paling banyak sebesar Rp1.000.000,00 (satu juta rupiah) (Bank Indonesia, 2018).

Menurut Candrawati (2014) dan Eri Susanti et al.(2019) perlu dilakukan perlindungan hukum terhadap para pengguna uang elektronik, hal ini disebabkan karena beberapa risiko yang dihadapi para pengguna uang elektronik antara lain hilangnya uang elektronik akan merugikan pemilik kartu karena dapat dimanfaatkan oleh orang yang menemukannya karena tidak terdapat PIN pelindung dalam penggunaan kartu uang elektronik dan tidak bisa mengklaim pihak penerbit untuk menggantinya. Selanjutnya uang elektronik berisiko terpakai 
berkali-kali dalam setiap transaksi akibat ketidaktahuan pengguna ataupun merchant yang menempelkan kartu berkali-kali pada alat sensor atau reader.

Adapun pihak-pihak yang berkaitan dengan terselenggaranya uang elektronik antara lain pengguna kartu uang elektronik, prinsipal yang mengelola sistem atau jaringan, penerbit yang mengeluarkan kartu elektronik, Acquirer yang bekerjasama dengan para merchant atau toko, merchant atau toko yang menerima pembayaran dengan uang elektronik, penyelenggara kliring dan yang terakhir adalah penyelenggara penyelesaian akhir (Bank Indonesia, 2011; Bank Indonesia, 2018; Bank Indonesia, 2019).

Beberapa jenis transaksi uang elektronik menurut Bahri (2010) antara lain Penerbitan (Issuance) kartu dan isi ulang (Top-up atau Loading). Kemudian transaksi pembayaran pada merchant atau pedagang dengan ketentuan yang sudah disepakati. Selanjutnya adalah transfer antar pemegang uang elektronik. Berikutnya adalah tarik tunai. Transaksi lainnya adalah Refund/Redeem atau penukaran kembali nilai uang elektronik kepada penerbit.

Menurut Bank Indonesia (2011) dan Abidin (2015) bahwa sistem pembayaran merupakan suatu sistem atau metode yang dipakai untuk menjadikan suatu transaksi lebih efektif dan efisien dalam kegiatan ekonomi di masyarakat yang melibatkan pihak-pihak yang terkait dalam kegiatan ekonomi tersebut.

\section{Perilaku Konsumen}

Perilaku konsumen merupakan suatu studi yang mempelajari seperti apa dan bagaiman suatu pribadi atau kelompok melakukan proses pemilihan, pembelian, penggunaan suatu produk atau pengalaman dalam memenuhi keinginan dan kepuasan akan kebutuhannya (Basu \& Handoko, 2011; Kotler \& Keller, 2016; Kotler, 2017). Perilaku pembelian konsumen tersebut akan dipengaruhi oleh beberapa faktor antara lain sosial, budaya, dan psikologis (Iqbal \& Ismail, 2011; Jeddi, 2013; Rambi, 2015; Hidayat, 2016; Dewi et al., 2017). Sedangkan menurut Peter \& Olson (2013) bahwa perilaku konsumen merupakan perkembangan hubungan antara kesadaran diri, perilaku, dan pengaruh lingkungan dalam setiap interaksi seluruh aspek kehidupan manusia. Hal senada juga disampaikan oleh Jeddi (2013) dan Enrico et al.(2014). Dari beberapa pendapat di atas bisa diambil kesimpulan bahwa perilaku konsumen merupakan semua aktivitas baik berupa tindakan ataupun secara psikologis yang memengaruhi seseorang pada saat sebelum melakukan pembelian, saat melakukan pembelian, kemudian saat penggunaan produk sampai habis dan proses evaluasi kegiatan.

\section{Perilaku Konsumtif}

Menurut Aprilia \& Hartono (2014) bahwa perilaku konsumtif merupakan perilaku seseorang yang terpengaruh oleh beberapa faktor di antaranya adalah faktor sosiologis yang diperlihat dalam konsumsi suatu produk dengan terlalu berlebihan tanpa suatu rencana dan tidak sesuai dengan kebutuhan. Sedangkan menurut Baudrillard (2013) bahwa perilaku konsumtif adalah suatu keinginan dari manusia untuk mengonsumsi suatu barang atau jasa secara tidak terbatas tanpa melihat kebutuhan tetapi hanya menonjolkan faktor keinginan semata. Selanjutnya menurut (Astuti, 2013; Saputra \& Listyani, 2017; Umanailo et al., 2018) bahwa 
perilaku konsumtif adalah pembelian suatu produk dengan tidak mempertimbangkan kebutuhan pokok tetapi hanya karena gengsi dan menjaga penampilan diri serta tertarik dengan kemasan dan hadiah atau diskon.

Kemudian pengertian perilaku konsumtif menurut beberapa ahli di antaranya (Ghufron \& Risnawita, 2011; Sarwono, 2011; Myers, 2012; Syamsu, 2012) bahwa seorang berperilaku konsumtif apabila sudah tidak bisa lagi membedakan mana keinginan dan mana kebutuhan, karena yang dipenuhi bukan lagi kebutuhan yang utama tetapi hanya ikut tren yang berkembang, menginginkan pengakuan sosial, dengan tidak peduli produk tersebut diperlukan atau tidak.

Beberapa faktor yang memengaruhi perilaku konsumtif antara lain adalah adalah faktor sosiologis dalam hal ini status sosial ekonomi dari orang tua sangat berpengaruh dalam pengukuran status sosial seseorang di masyarakat. Penggolongan status sosial ini bisanya didasarkan pada ukuran tertentu antara lain ukuran kekuasaan, kehormatan, popularitas, ketokohan, kekayaan, ilmu pengetahuan (Ali, M, 2011). Perilaku konsumtif seorang remaja bisa dipengaruhi oleh status ekonomi orang tua yang dimilikinya. Remaja yang memiliki orang tua yang kaya akan tebiasa berbelanja kebutuhan hidupnya dengan mudah tanpa kendala secara keuangan. Selain itu remaja yang keluarganya menjadi tokoh masyarakat dan terpandang serta popular akan berusaha untuk menjaga popularitas dan kelas sosialnya dengan selalu berpenampilan dan bergaya atau berbusana yang sesuai dengan statusnya (Sipunga \& Muhammad, 2014).

Sehingga kesimpulan yang bisa diambil adalah bahwa status sosial ekonomi orang tua merupakan suatu kedudukan yang diperoleh karena orang tua yang memiliki kekayaan, tingkat pendidikan dan popularitas serta ketokohan di lingkungan masyarakat.

Faktor selanjutnya yang memengaruhi perilaku konsumtif yaitu kelompok referensi atau kelompok sosial yang akan dijadikan acuan bagi seseorang yang bukan bagian dari kelompoknya dan berpengaruh terhadap tingkah laku dan kepribadiannya. Kelompok referensi ini datang dari orang-orang yang berada di sekelilingnya. Kelompok referensi ini bisa memberikan pengaruh terhadap perilaku seseorang dalam melakukan suatu pembelian produk dengan memberikan informasi tentang deskripsi produk atau keunggulan suatu produk untuk dijadikan acuan dalam membeli suatu barang atau jasa (Erli Ermawati \& E.P, 2011; Hamdan, 2013; Pratiwi \& Yani, 2016).

Perilaku konsumtif seseorang secara operasional bisa dilihat dari beberapa indikator antara lain barang atau jasa yang dibeli tidak dilihat dari manfaatnya tetapi hanya karena menginkan hadiah yang ada. Kemudian barang dan jasa yang dibeli hanya karena dikemas secara unik dan menarik karena kemasan suatu produk yang unik dan beda dari produk lainnya serta menarik membuat seseorang berkeinginan untuk membeli produk tersebut. Selain itu barang atau jasa yang dibeli hanya untuk meningkatkan gengsi dan penampilan diri, demi gengsi menjadikan seseorang akan membeli produk yang dianggap bisa mempertahankan gaya dan penampilan dibanding membeli produk yang memang lebih diperlukan dalam kehidupannya. Selanjutnya produk yang dibeli hanya karena dilihat lebih eksklusif dan mewah baik dari bentuk maupun harganya bukan karena nilai 
kegunaan atau manfaatnya. Seseorang akan lebih menyukai suatu barang atau jasa yang dianggap eksklusif atau mewah karena secara umum perilaku manusia menyukai hidup mewah sehingga manusia akan berusaha untuk memiliki sesuatu hal yang identik dengan suatu yang mewah (Baudrillard, 2013) dan (Saputra \& Listyani, 2017).

Berikutnya perilaku konsumtif bisa dilihat dari barang dan jasa yang dibeli hanya untuk mempertahankan status sosial. Produk yang digunakan oleh seseorang dianggap sebagai simbol dan status sosial orang tersebut. Diharapkan barang atau jasa yang dibeli dapat meningkatkan status dihadapan orang lain. Selanjutnya barang dan jasa yang dibeli karena unsur konfromitas terhadap model iklan dari produk tersebut. Seseorang menggunakan suatu produk karena ketertarikannya agar dapat menyerupai seperti model yang diidolakanya yang ada dalam iklan tersebut. Selain itu barang dan jasa yang dibeli hanya karena harga mahal bukan berdasarkan kebutuhan dengan harapan memunculkan kepercayaan diri yang lebih besar dihadapan orang lain merupakan indikator perilaku konsumtif lainnya. Kemudian indikator perilaku konsumtif berikutnya adalah kecendurangan untuk menggunakana barang atau jasa yang sama dari berbagai merek. Konsumen akan cenderung menggunakan produk dengan jenis yang sama dengan merek yag lain dari produk sebelumnya yang ia gunakan, meskipun produk tersebut belum habis dipakainya (Baudrillard, 2013) dan (Umanailo et al., 2018).

Pengertian mahasiswa menurut Kemendikbud RI (2020) adalah seseorang atau individu yang sedang menjalankan studi di suatu perguruan tinggi atau kampus, yang apabila dilihat dari struktur pendidikan di Indonesia mahasiswa memiliki status tertinggi dalam suatu jenjang pendidikan. Mahasiswa yang merupakan bagian dari kalangan muda dan remaja memiliki perilaku konsumtif yang cukup dominan khususnya mahasiswi. Faktor rasional dan faktor emosional sangat berpengaruh terhadap perilaku konsumtif pada mahasiswa atau remaja (Syamsu, 2012).

Mahasiswa yang menggunakan faktor emosionalnya saja dalam mengonsumsi suatu barang atau jasa maka akan berperilaku konsumtif dan hanya mempertimbangkan penampilan, gaya dan gengsi, tetapi bagi mahasiswa yang mempertimbangkan faktor rasional akan selalu melihat manfaat dan kegunaan serta harga produk yang berwujud mode atau style popular. Sedangkan masyarakat akan memandang mahasiswa sebagai seorang intelektual dengan pola pikir yang matang dan maju, memiliki penampilan yang rapih, sopan dan menarik. Hal inilah yang menjadikan mahasiswa berusaha menjadikan dirinya untuk berpenampilan seperti pandangan masyarakat tersebut (Ali, M, 2011).

\section{Pengaruh Penggunaan Uang Elektronik Terhadap Perilaku Konsumtif}

Penelitian tentang perilaku konsumen dan uang elektronik sudah dilakukan oleh beberapa peneliti, di antaranya adalah (Aksami \& Jember, 2019; Aprilia \& Hartono, 2014; Daliyah \& Patrikha, 2020; Hizbul Hadi Nawawi, 2020; Khairi \& Gunawan, 2019; Kumala \& Mutia, 2020; Kurniawan, 2017; Miftahul Rizqa Khairi, 2019; Mujahidin, 2020; Mujahidin \& Rika Pristian Fitri Astuti, 2020; Noto, Anniza, \& Serenata, 2019; Nurdian et al., 2020; Ramadani, 2016; 
Ramadhani, 2019; Rofiqoh et al., 2019; Syifa, 2019; Tresnaatmaja, 2019). Beberapa hasil penelitian tersebut menunjukan hasil yang cenderung sama yaitu menyebutkan bahwa penggunaan kartu debit atau uang elektronik memiliki pengaruh yang positif dan signifikan terhadap perilaku konsumtif masyarakat. Jika penggunaan kartu debit atau uang elektronik semakin tinggi maka konsumsi masyarakat terhadap barang dan jasa juga akan meningkat secara signifikan. Jika dilihat secara psikologis, kemudahan seseorang dalam membelanjakan uang akan lebih tinggi pada saat memegang uang non-tunai dibandingkan uang tunai. Sehingga seseorang akan lebih konsumtif ketika sering menggunakan uang elektronik. Hal ini disebabkan karena penggunaan uang elektronik jauh lebih mudah, aman, nyaman, cepat, dan efisien dibanding jika memakai uang tunai. Sehingga bisa disimpulkan bahwa penggunaan uang elektronik berpengaruh terhadap perilaku konsumtif masyarakat pada umumnya dan mahasiswa pada khususnya.

\section{Kerangka Berfikir dan Hipotesis Penelitian}

Uang elektonik memberikan suatu kemudahan dalam bertransaksi, penggunanya dapat mentransfer uang atau membayar sesuatu hanya dengan menggunakan smartphone mereka tanpa perlu keluar rumah. Dengan kemudahan tersebut, seseorang bisa saja tanpa sadar berbelanja semua keinginan mereka melalui uang elektronik. Akibatnya muncullah perilaku konsumtif yang secara tidak sadar tanpa diikuti adanya perencanaan dan tidak adanya pertimbangan yang mendasar dari pembelian suatu barang tersebut. Kerangka berpikir dalam penelitian ini mengasumsikan bahwa penggunaan uang elektronik akan berpengaruh terhadap perilaku konsumtif pada diri seseorang.

Berdasarkan landasan teori yang dipakai, dapat disimpulkan hipotesis yang diajukan oleh penelitian yaitu diduga penggunaan uang elektronik memiliki pengaruh yang positif dan signifikan terhadap perilaku konsumtif mahasiswa.

\section{METODE PENELITIAN}

Berdasar variabel yang diteliti, masalah yang dirumuskan dan hipotesis yang ada maka penelitian ini menggunakan metode kuantitatif dengan jenis penelitian survey dengan angket. Jenis metode penelitian ini digunakan karena sesuai dengan tujuan yang ingin dicapai, yaitu peneliti berusaha mengetahui apakah penggunaan uang elektronik diduga memiliki pengaruh terhadap perilaku konsumtif Mahasiswa.

Adapun Populasi penelitian ini yaitu 430 Mahasiswa dari Prodi Pendidikan Ekonomi Universitas Indraprasta PGRI Jakarta dengan sampel sebanyak 81 orang. Teknik sampling yang digunakan adalah sampling acak sederhana (simple random sampling) yaitu anggota sampel diambil dari populasi yang dilakukan secara acak dengan tidak melihat strata yang terdapat di populasi tersebut (Sugiyono, 2019). Pengumpulan data melalui kuesioner menggunakan format pengukuran skala Likert. Skala Likert menurut Sugiyono (2019) adalah alat yang digunakan untuk pengukuran suatu pendapat, sikap dan persepsi dari seorang atau beberapa orang tentang suatu permasalahan sosial. Setelah dilakukan penentuan instrumen penelitian pada dua variabel penggnaan uang elektronik (X) dan perilaku 
konsumtf (Y), kemudian diuji validitas dan reabilitasnya. Teknk analisis data menggunakan regresi linier sederhana, analisis koefesen korelasi, analisis koefisien determinasi, kemudian untuk hipotesis penelitian dibuktikan dengan menggunakan Uji T.

\section{HASIL DAN PEMBAHASAN}

\section{Analisis Deskriptif}

Hasil penelitian menunjukkan perolehan data sejumlah 81 responden yang terdiri dari laki-laki sejumlah 19 responden dan perempuan sejumlah 62 responden sebagaimana yang disajikan pada Tabel 1 di bawah ini.

\section{Tabel 1.}

\section{Karakteristik Jenis Kelamin Responden}

\begin{tabular}{ccc}
\hline JENIS KELAMIN & RESPONDEN & PERSENTASE \\
\hline Laki-laki & 19 & $23,46 \%$ \\
Perempuan & 62 & $76,54 \%$ \\
Jumlah & 81 & $100 \%$ \\
\hline \multicolumn{2}{c}{ Sumber: Data dibuat oleh peneliti, (2020) }
\end{tabular}

Penelitian ini menilai tiga aspek. Aspek pertama adalah mengukur responden dalam hal ketertarikan dan penggunaan uang eletronik. Aspek kedua adalah mengukur ketertarikan responden tapi tidak menggunakan uang elektronik. Aspek ketiga adalah mengukur responden atas ketidaktertarikannya dan tidak menggunakan uang elektronik. Hasil penelitian tersebut ditunjukkan pada Tabel 2. Berdasarkan Tabel 2, menunjukkan bahwa aspek pertama menempati persentase tertinggi sebesar 76,54\%, sementara aspek kedua sebesar 17,28\% dan aspek ketiga sebesar $6,17 \%$. Artinya dari 81 orang responden yang diteliti, sebagian besar tertarik dan menggunakan uang elektronik.

Tabel 2

Ketertarikan Penggunaan Uang Elektronik Oleh Responden

\begin{tabular}{lcc}
\hline TINGKAT KETERTARIKAN & RESPONDEN & PERSENTASE \\
\hline Tertarik dan Menggunakan & 62 & $76,54 \%$ \\
Tertarik tapi tidak menggunakan & 14 & $17,28 \%$ \\
Tidak Tertarik dan tidak menggunakan & 5 & $6,17 \%$ \\
Jumlah & 81 & 100 \\
\hline \multicolumn{2}{c}{ Sumber: Data dibuat oleh peneliti, (2020) }
\end{tabular}

Faktor-faktor yang mempengaruhi ketertarikan untuk menggunakan uang elektronik antara lain; (1) Praktis dan mudah; (2) Banyak promo yang ditawarkan. Kemudian responden yang tertarik tapi tidak menggunakan uang elektronik dilatarbelakangi oleh faktor; (1) Pengetahuan tentang uang elektronik rendah; (2) Lebih nyaman menggunakan uang tunai; (3) khawatir akan biaya tambahan jika menggunakan uang elektronik. Sedangkan responden yang tidak tertarik dan tidak menggunakan uang elektronik disebabkan oleh factor (1) tidak tahu manfaat dari 
uang elektronik; (2) tidak mau berisiko; (3) tidak mau ribet dengan urusan bank; (4) lebih nyaman pakai uang tunai.

\section{Analisis Regresi Linear Sederhana}

Analisis regresi sederhana ini untuk melihat pola hubungan antar variabel X yaitu penggunaan uang elektronik dengan variabel $\mathrm{Y}$ yaitu perilaku konsumtif mahasiswa.

Berdasarkan perhitungan diperoleh nilai $a=42,26$ dan koefisien $b=0,32$ sehingga ditemukan persamaaan regresinya adalah $\mathrm{Y}=42,26+0,32 \mathrm{X}$. Dari persamaan regresi tersebut dapat diartikan bahwa jika penggunaan uang elektronik bernilai 0, atau tidak menggunakan uang elektronik maka kepuasan konsumen sebesar a atau 42,26. Sedangkan penggunaan uang elektronik memiliki pengaruh sebesar $\mathrm{b}$ atau 0,32 terhadap perilaku konsumtif mahasiswa, sehingga penggunaan uang elektronik ditingkatkan per 1 satuan maka perilaku konsumtif mahasiswa meningkat sebesar b atau 0,32.

\section{Analisis koefisien korelasi sederhana}

Analisis koefisien korelasi sederhana (r) adalah sebuah nilai yang digunakan untuk melihat derajat keeratan hubungan antara dua variabel yaitu variabel penggunaan uang elektronik (X) dan variabel perilaku konsumtif mahasiswa (Y). Dari hasil perhitungan korelasi diperoleh nilai koefisien korelasi $r_{\mathrm{xy}}=0,325$, jika dilihat dari pedoman interpretasi koefisien korelasi dari Sugiyono (2019) nilai tersebut menunjukkan arti bahwa terdapat pengaruh yang rendah antara penggunaan uang elektronik $(\mathrm{X})$ terhadap perilaku konsumtif mahasiswa $(\mathrm{Y})$.

\section{Analisis koefisien Determinasi}

Metode koefisien determinasi dapat dengan mengkuadratkan koefisien korelasi. Metode ini dipakai untuk mengetahui seberapa besar kontribusi variabel $\mathrm{X}$ yaitu penggunaan uang elektronik terhadap variabel $\mathrm{Y}$ yaitu perilaku konsumtif mahasiswa.

Dari hasil perhitungan didapatkan koefisien determinasi (KD) sebesar 10,56\%. Hasil ini dapat diartikan bahwa penggunaan uang elektronik memberikan kontribusi terhadap perilaku konsumtif sebesar $10,56 \%$ sedangkan sisanya sebesar $89,44 \%$ adalah berasal dari kontribusi faktor-faktor lain.

\section{Pengujian Hipotesis}

Dari hasil perhitungan diperoleh $t_{\text {hitung }}$ sebesar 3,085. Kemudian dilanjutkan dengan mencari $t_{\text {tabel, }}$ yaitu untuk $\mathrm{t}-\mathrm{a}(\mathrm{dk}=\mathrm{n}-2)$ maka diperoleh $\mathrm{t}_{\text {tabel }}=1,664$. Kemudian langkah selanjutnya adalah membandingkan $t_{\text {hitung }}$ dengan $t_{\text {tabel }}$ untuk mengetahui keberartian korelasi penggunaan uang elektronik terhadap perilaku konsumtif mahasiswa. Kriteria pengujian dalam penelitian ini adalah:

a) Ho diterima jika $t_{\text {hitung }}<t_{\text {tabel }}$ atau 3,085 $<1,664$

b) Ha diterima $t_{\text {hitung }}>t_{\text {tabel }}$ atau 3,085 $>1,664$

dari hasil perhitungan diperoleh $t_{\text {hitung }}>\mathrm{t}_{\text {tabel }}(3,085>1,664)$, berarti Ho ditolak 
dan Ha diterima. Maka hal ini menunjukkan bahwa penggunaan uang elektronik memiliki pengaruh yang positif dan signifikan terhadap perilaku konsumtif Mahasiswa Pendidikan Ekonomi Universitas Indraprasta PGRI. Hasil penelitian ini memperkuat hasil penelitian sebelumnya yang dilakukan oleh (Daliyah \& Patrikha, 2020a; Mujahidin, 2020; Nurdian et al., 2020; Tresnaatmaja, 2019) yang menunjukkan bahwa penggunaan kartu debit dan uang elektronik memiliki pengaruh yang positif dan signifikan terhadap perilaku konsumtif dari mahasiswa.

Kehadiran uang elektronik yang digunakan sebagai instrumen dalam pembayaran berbasis aplikasi ini menghilangkan kendala dan memudahkan dalam setiap transaksi sehingga memiliki potensi yang cukup besar untuk meningkatkan konsumsi masyarakat pada umumnya dan mahasiswa pada khususnya. Walaupun dari hasil perhitungan analisis korelasi menunjukkan korelasi yang rendah dan hanya memberikan kontribusi sebesar $10,56 \%$ dari perhitungan koefisien determinasi, yang berarti kontribusi variabel lainnya cukup besar yaitu sekitar $89,44 \%$, tapi tetap saja faktor kemudahan menggunakan uang elektronik ini dapat memicu peningkatan perilaku konsumtif dari mahasiswa.

Setiap manusia melakukan pembelanjaan, baik remaja, dewasa hingga orang tua. Pembelanjaan ini selain untuk memenuhi kebutuhan pokok hidupnya juga dilakukan untuk sekedar memuaskan keinginannya yang tidak terbatas. Keinginan untuk memenuhi kepuasan yang tidak terbatas inilah yang dapat menimbulkan sikap atau perilaku konsumtif, sikap konsumtif yaitu mengeluarkan uang yang banyak demi terpenuhinya keinginan tersebut. Perilaku konsumtif biasanya tidak didasarkan pada kebutuhan saja, tetapi didorong oleh keinginan dan hasrat yang ada pada diri seseorang.

Perilaku konsumtif banyak terjadi pada kalangan mahasiswa, khususnya mahasiswi, hal ini terlihat dari hasil yang diperoleh dalam penelitian yang disampaikan di atas bahwa responden wanita sebanyak 62 orang atau 76,54\% semuanya menggunakan uang elektronik, hal ini cukup memberikan bukti bahwa penggunaan uang elektronik ini cukup berpengaruh terhadap perilaku konsumtif mahasiswa terutama mahasiswi. Remaja atau mahasiswa yang memiliki perilaku konsumtif biasanya hanya mengedepankan faktor emosional saja dalam berbelanja yaitu untuk gaya hidup dan bermacam-macam alasan yang sebenarnya kurang penting.

\section{E. SIMPULAN}

Berdasarkan hasil penelitian dan analisis di atas diperoleh nilai tingkat sensitivitas perilaku konsumtif terhadap penggunaan uang elektronik itu sendiri adalah 32\% yang ditunjukkan dengan koefisien regresi $\mathrm{Y}=42,26+0,32 \mathrm{X}$. Sedangkan koefisien korelasi menunjukkan $r=0,325$ dan koefisien determinasi (KD) sebesar 10,56\%. Dalam uji hipotesis nilai $t_{\text {hitung }}>t_{\text {tabel }}$ yaitu 3,085 $>1,664$, artinya bisa disimpulkan bahwa penggunaan uang elektronik memiliki pengaruh yang positif dan signifikan terhadap perilaku konsumtif dari mahasiswa Pendidikan Ekonomi Universitas Indraprasta PGRI tetapi memiliki korelasi yang rendah dengan kontribusi penggunaan uang elektronik terhadap perilaku konsumtif mahasiswa sebesar $10,56 \%$ dan sisanya sebesar $89,44 \%$ dipengaruhi oleh faktor lainnya. Hal ini berarti bahwa penggunaan uang elektronik dapat 
meningkatkan perilaku konsumtif pada diri mahasiswa. Penggunaan pembayaran non-tunai dapat menyebabkan pengeluaran konsumsi mahasiswa juga semakin meningkat. Penggunaan uang elektronik memiliki kemudahan dan kecepatan sehingga penggunaannya semakin meningkat di kalangan mahasiswa. Oleh sebab itu, penggunaan uang elektronik dapat memengaruhi sifat konsumtif mahasiswa.

Berdasarkan kesimpulan tersebut, maka diharapkan; (1) Mahasiswa agar dapat memilah-milah mana yang merupakan suatu kebutuhan yang memang harus dipenuhi dan mana yang hanya sebuah keinginan semata; (2) Mahasiswa agar lebih bijak dalam melakukan transaksi pembayaran khususnya saat menggunakan uang elektronik; (3) Mahasiswa diharapkan bisa meminimalisir pengeluaran mereka; (4) Tidak hanya mengikuti apa yang sedang trend saat ini tetapi perlu menyesuaikan dengan pmempertimbangkan kemampuan biaya dan kebutuhan pribadi masing-masing; (5) Bagi peneliti selanjutnya agar dapat menggali variabel lain yang masih cukup banyak serta bervariasi yang akan berpengaruh terhadap perilaku konsumtif mahasiswa dengan menambahkan subyek penelitian dan dengan latar belakang yang berbeda untuk mendapatkan hasil yang lebih baik. 


\section{DAFTAR PUSTAKA}

Abidin, M. S. (2015). Dampak Kebijakan E-Money Di Indonesia Sebagai Alat Sistem Pembayaran Baru. Jurnal Akuntansi UNESA, 3(2), 1-21.

Aksami, N. M. D., \& Jember, I. M. (2019). Analisis Minat Penggunaan Layanan E-Money Pada Masyarakat Kota Denpasar. E-Jurnal Ekonomi Pembangunan Universitas Udayana, 8(9), 2439-2470.

Ali, M, . Asrori M. (2011). Psikologi Remaja: Perkembangan Peserta Didik. Bumi Aksara.

Aprilia, D., \& Hartono. (2014). Analisis Sosiologis Perilaku Konsumtif Mahasiswa (Studi pada Mahasiswa FISIP Universitas Lampung). Jurnal Sosiologi.

Astuti, E. D. (2013). Perilaku Konsumtif dalam Membeli Barang pada Ibu Rumah Tangga di Kota Samarinda. Psikoborneo; Jurnal Ilmiah Psikologi, 1(2), 7983.

Bahri, A. S. (2010). Konsep Uang Elektronik Dan Peluang Implementasinya Pada Perbankan Syariah. UIN Syarif Hidayatullah.

Bank Indonesia. (2011). Sistem Pembayaran di Indonesia. Bank Indonesia. http://www.bi.go.id/id/sistem-pembayaran/di-indonesia

Bank Indonesia. (2018). Peraturan Bank Indonesia Nomor 20/6/PBI/2018 tentang Uang Elektronik. Bank Indonesia. http://www.bi.go.id/

Bank Indonesia. (2019). Informasi Perizinan Penyelenggara dan Pendukung Jasa Sistem Pembayaran. Bank Indonesia. https://www.bi.go.id/id/sistem pembayaran/informasiperizinan/Contents/Default.aspx.

Basu, S., \& Handoko, H. (2011). Manajemen Pemasaran, Analisis Perilaku. Konsumen. BPFE.

Baudrillard, J. (2013). Masyarakat konsumsi. Kreasi Wacana.

Candrawati, N. N. A. (2014). Perlindungan Hukum Terhadap Pemegang Kartu EMoney Sebagai Alat Pembayaran Dalam Transaksi Komersial. Jurnal Magister Hukum Udayana (Udayana Master Law Journal), 3(1), 1-16. https://doi.org/10.24843/jmhu.2014.v03.i01.p03

Daliyah, R., \& Patrikha, F. D. (2020). Analisis Perilaku Konsumsi Pengguna Aplikasi E-Money Pada Mahasiswa Fakultas Ekonomi Universitas Negeri Surabaya. Jurnal Pendidikan Tata Niaga, 8(3), 946-952.

Dewi, H. N., Sukartiko, A. C., \& Pamungkas, A. P. (2017). Consumer behavior in their buying decision process of agro-geographical indication products in Yogyakarta. Agroindustrial Journal, 4(1), 203-208.

Enrico, A., Aron, R., \& Oktavia, W. (2014). The Factors that Influenced Consumptive Behavior: A Survey of University Students in Jakarta. International Journal of Scientific and Research Publications, 4(1), 1-6. 
https://doi.org/10.2139/ssrn.2357953

Eri Susanti, N. D. M., Atmadja, I. B. P., \& Darmadi, A. A. S. W. (2019). Perlindungan.Hukum Bagi Pemilik E-Money Yang Diterbitkan Oleh Bank Dalam Transasksi Non-tunai. Kertha Semaya : Journal Ilmu Hukum, 7(11), 1-14. https://doi.org/10.24843/km.2019.v07.i03.p15

Erli Ermawati, \& E.P, I. (2011). Hubungan Antara Konsep Diri Dengan Perilaku Konsumtif Pada Remaja Di Smp N 1 Piyungan. Jurnal Spirits, 2(1), 1-12.

Ghufron, \& Risnawita. (2011). Teori-teori psikologi. Ar-ruzz media.

Hamdan. (2013). Hubungan antara konformitas dengan perilaku konsumtif pada remaja putri. Jurnal Psikostudia Universitas Mulawarman, 2(2), 68-75.

Hidayat, R. (2016). Faktor-Faktor yang Memengaruhi Consumer Decision Making Process (Studi Kasus Rumah Makan Bebek Sinjai Madura). JIEMS (Journal of Industrial Engineering and Management Systems), 9(2), 77-95. https://doi.org/10.30813/jiems.v9i2.40

Hizbul Hadi Nawawi. (2020). Penggunaan E-wallet di Kalangan Mahasiswa. Jurnal Emik, 3(2), 189-205.

Iqbal, S., \& Ismail, Z. (2011). Buying Behavior: Gender and Socioeconomic Class Differences on Interpersonal Influence Susceptibility. International Journal of Business and Social Science, 2(4), 55-66.

Jeddi, S. (2013). Consumer behavior and Consumer buying decision process. International Jornal of Business and Behavioral Sciences, 3(5), 20-23.

Kemendikbud RI. (2020). Kamus Besar Bahasa Indonesia (KBBI). Kemendikbud RI. https://kbbi.kemdikbud.go.id/

Khairi, M. R., \& Gunawan, E. (2019). Analisis Penggunaan Alat Pembayaran Menggunakan Kartu (APMK) dan E-Money Terhadap Konsumsi Masyarakat di Banda Aceh. Jurnal Ilmiah Mahasiswa Ekonomi Islam, 1(1), 19-36.

Kotler, P. (2017). Principles of Marketing (Seventh Eu). Pearson Education.

Kotler, P., \& Keller, L. . (2016). Marketing Management (Fifteenth). Pearson Education.

Kumala, I., \& Mutia, I. (2020). Pemanfaatan Aplikasi Dompet Digital Terhadap Transaksi Retail Mahasiswa. Seminar Nasional Riset Dan Teknologi, 64-69.

Kurniawan, C. (2017). Analisis Faktor-Faktor Yang Memengaruhi Perilaku Konsumtif Ekonomi Pada Mahasiswa. Jurnal Media Wahana Ekonomika, 13(4), 107-118.

Miftahul Rizqa Khairi, E. G. (2019). Analisis Penggunaan Alat Pembayaran Menggunakan Kartu (Apmk) Dan E-Money Terhadap Konsumsi Masyarakat Di Banda Aceh. Jurnal Ilmiah Mahasiswa Ekonomi Islam, 1(1), 19-36. 
Mujahidin, A. (2020). Pengaruh Fintech e-wallet Terhadap Perilaku Konsumtif Pada Generasi Millennial. Inovbiz: Jurnal Inovasi Bisnis, 8(2), 143-150. https://doi.org/10.35314/inovbiz.v8i2.1513

Mujahidin, A., \& Rika Pristian Fitri Astuti. (2020). Pengaruh Fintech e-wallet Terhadap Perilaku Konsumtif Pada Generasi Millennial. Inovbiz: Jurnal Inovasi Bisnis, 8(2), 143-150. https://doi.org/10.35314/inovbiz.v8i2.1513

Myers, D. G. (2012). Psikologi Sosial. Salemba Humanika.

Noto, A. P., Anniza, A., \& Serenata, S. D. T. (2019). Pengaruh Uang Elektronik Terhadap Perilaku Konsumtif Mahasiswa Fakultas Matematika dan Ilmu Pengetahuan Alam Universitas Sebelas Maret. 1-5. https://ideas.repec.org/p/osf/osfxxx/e73v5.html

Nurdian, A., Sari, D., Malik, Z. A., \& Hidayat, R. (2020). Prosiding Hukum Ekonomi Syariah Pengaruh Penggunaan Uang Elektronik (E-Money) terhadap Perilaku Konsumen. Prosiding Hukum Ekonomi Syariah, 6(1), 14.

Oktafia Mustika Rani, M. A. H. (2020). Budaya Konsumerisme Petani Perkotaan: Studi Gaya Hidup Petani Di Kelurahan Jeruk, Lakarsantri, Surabaya. Jurnal Analisa Sosiologi, 9(2), 452-477.

Peter, J. P., \& Olson, J. C. (2013). Consumer Behavior. Perilaku konsumen dan Strategi Pemasaran. Erlangga.

Pratiwi, I. W., \& Yani, R. E. (2016). Hubungan Konformitas Dengan Perilaku Konsumtif Pada Remaja. Jp3sdm, 4(1), 11-21.

Raharjo Jati, Wasisto. (2015). Less Cash Society: Menakar Mode Konsumerisme Baru Kelas Menengah Indonesia. Jurnal Sosioteknologi, 14(2), 102-112. https://doi.org/10.5614/sostek.itbj.2015.14.2.1

Ramadani, L. (2016). Pengaruh Penggunaan Kartu Debit dan Uang Elektronik ( E- Money ) Terhadap Pengeluaran Konsumsi Mahasiswa. JESP, 8(1), 1-8.

Ramadhani, R. H. (2019). Pengaruh Literasi Keuangan , Electronic Money , Gaya Hidup , dan Kontrol Diri Terhadap Perilaku Konsumtif Mahasiswa. Repositori Institusi USU, Univsersitas Sumatera Utara.

Rambi, W. (2015). the Influence of Consumer Behavior on Purchase Decision Xiaomi Cellphone in Manado. Jurnal EMBA: Jurnal Riset Ekonomi, Manajemen, Bisnis Dan Akuntansi, 3(2), 917-927. https://doi.org/10.35794/emba.v3i2.9247

Rofiqoh, D. A. A., Baehaqi, A., Putra, A., Avianti, A., Sitorus, J. A., \& Larasati Felinurokhim. (2019). The Influence Of E-Wallet On Consumptive Behavior Of Milenial Generation In Jabodetabek (Case Study On Ovo Services). ResearchGate, 1-11.

Rohini, D. (2018). Pengaruh Belanja Online di Media Sosial terhadap Perilaku Konsumtif Siswa-Siswi SMA Muhammadiyah Imogiri Bantul. (Skripsi). UIN 


\section{SUNAN KALIJAGA YOGYAKARTA.}

Saputra, A. D., \& Listyani, R. H. (2017). Masyarakat Konsumsi ( Studi Deskriptif Gejala Konsumerisme Jasa Tato Pada Masyrakat Kota Surabaya ). Paradigma, 05(03), 1-11.

Sarwono, S. W. (2011). Psikologi Sosial. Salemba Humanika.

Sipunga, P. N., \& Muhammad, A. H. (2014). Kecenderungan Perilaku Konsumtif Remaja Di Tinjau Dari Pendapatan Orang Tua Pada Siswa-Siswi Sma Kesatrian 2 Semarang. Journal of Social and Industrial Psychology, 3(1), $62-68$.

Sugiyono. (2019). Metode Penelitian Kuantitaif,Kualitatif, dan R\&D. Alfabeta.

Syamsu, Y. (2012). Psikologi Perkembangan Anak dan Remaja. Remaja Rosdakarya.

Syifa, L. (2019). Pengaruh Kemudahan Penggunaan Mobile Banking terhadap Perilaku Konsumtif Mahasiswa FITK UIN Syarif Hidayatullah Jakarta. UIN SYARIF HIDAYATULLAH, JAKARTA.

Tresnaatmaja, L. (2019). Pengaruh Persepsi Manfaat Kartu Debit Dan E-Money Terhadap Perilaku Konsumtif Mahasiswa. Universitas Katolik Soegijapranata Semarang.

Umanailo, M. C. B., Nawawi, M., \& Pulhehe, S. (2018). Konsumsi Menuju Konstruksi Masyarakat Konsumtif. Simulacra: Jurnal Sosiologi, 1(2), 203211. https://doi.org/10.21107/sml.v1i2.4995

Usman, R. (2017). Karakteristik Uang Elektronik Dalam Sistem Pembayaran. Yuridika, 32(1), 134-165. https://doi.org/10.20473/ydk.v32i1.4431 